\title{
PERTUMBUHAN DAN HASIL JAMUR TIRAM PUTIH (Pleurotus ostreatus (Jacq) P. Kumm) PADA BERBAGAI KOMPOSISI MEDIA TANAM
}

\section{THE EFFECT OF PLANTING MEDIA COMPOSITION ON THE GROWTH AND YIELD OF OYSTER MUSHROOMS (Pleurotus ostreatus (Jack) P. Kumm}

\author{
Fitri Kurniati, Yaya Sunarya, Rina Nurajijah \\ Jurusan Agroteknologi, Fakultas Pertanian, Universitas Siliwangi \\ Korespondensi : fitri.kurniati61@gmail.com
}

\begin{abstract}
ABSTRAK
Pada umumnya petani membuat media jamur tiram putih (Pleurotus ostreatus (Jacq) P. Kumm) berbahan dasar serbuk kayu, diantaranya sengon. Namun ketersediaanya semakin hari semakin berkurang, sehingga diperlukan alternatif bahan lain sebagai substitusi, misalnya sekam padi yang mengandung serat tinggi dengan komposisi utama selulosa 33\% sampai 44\%, lignin $19 \%$ sampai $47 \%$, hemniselulosa $17 \%$ sampai $26 \%$, pentose $16,95 \%$ sampai $21,95 \%$ dan silica 13\%. Tujuan penelitian adalah mengetahui pertumbuhan dan hasil jamur tiram putih pada berbagai komposisi media tanam. Penelitian dilakukan pada bulan Maret sampai dengan Juni 2019 di Kecamatan Bungbulang Kabupaten Garut. Rancangan percobaan yang digunakan adalah Rancangan Acak Kelompok (RAK) sederhana, diulang sebanyak 5 kali. Perlakuan terdiri dari $\mathrm{p}_{0}\left(100 \%\right.$ serbuk kayu), $\mathrm{p}_{1}(15 \%$ sekam padi $+85 \%$ serbuk kayu $), \mathrm{p}_{2}(30 \%$ sekam padi + $70 \%$ serbuk kayu), $\mathrm{p}_{3}\left(45 \%\right.$ sekam padi $+55 \%$ serbuk kayu) dan $\mathrm{p}_{4}(60 \%$ sekam padi $+40 \%$ serbuk kayu). Analisis data menggunakan uji Fisher pada taraf kesalahan 5\% dan dilanjutkan dengan Uji Jarak berganda Duncan untuk mengetahui pertumbuhan dan hasil paling baik pada perlakuan tersebut. Hasil penelitian menunjukkan bahwa jumlah tubuh buah dan bobot basah jamur tiram putih yang lebih baik terdapat pada komposisi $15 \%$ media sekam $+85 \%$ serbuk kayu, yaitu 38,70 tubuh buah dan bobot basah 493,98 g.
\end{abstract}

Kata kunci: Jamur tiram putih, media, sekam padi

\section{ABSTRACT}

Rice husk is the waste that contains cellulose $33 \%$ to $44 \%$, lignin $19 \%$ to $47 \%$, hemicellulose $17 \%$ to $26 \%$, pentose $16,94 \%$ to $21,95 \%$, and silica $13 \%$, so can be used as a mixture for planting media of oyster mushrooms. The study was aimed to determine the media that have good effect on the growth and yield of oyster mushrooms (Pleurotus ostreatus (Jack) P. Kumm. The Research was conducted from March to June 2019 in Bungbulang, Garut, using Randomized Block Design (RBD) consisted of 5 treatment and 5 replication, that were $\mathrm{p} 0$ (rice husk $0 \%$ +sawdust 100\%), p1 (rice husk 15\% + sawdust 85\%), p2 (rice husk 30\% + sawdust $70 \%$ ), p3 (rice husk 45\% +sawdust 55\%), and p4 ((rice husk 60\% +sawdust 40\%). The results of this study showed that, rice husk $15 \%+$ sawdust $85 \%$ as a mixture for planting media of oyster mushrooms gave the best effect on the number of fruit mushroom body that was 38,78 and mushroom wet weight that was $93,98 \mathrm{~g}$.

Keywords : rice husk, media, oyster mushroom 


\section{PENDAHULUAN}

Media pada budidaya jamur tiram putih harus memenuhi persyaratan bagi pertumbuhan miselium, yaitu mengandung unsur C (karbon) dalam bentuk karbohidrat dalam jumlah cukup tinggi. Media juga harus mengandung unsur $\mathrm{N}$ dalam bentuk ammonium, nitrat atau N-organik. Unsurunsur ini akan diubah oleh jamur menjadi protein. Selain itu, media tumbuh jamur juga harus mengandung unsur $\mathrm{Ca}$ yang berfungsi untuk menetralkan asam oxalate yang dikeluarkan oleh miselium dan memiliki partikel yang tidak mudah memadat sehingga tidak menghambat ruang pertumbuhan miselium (Djarijah dan Djarijah, 2001).

Media tanam jamur tiram putih konvensional adalah serbuk kayu sengon (Paraserianthes falcataria) yang mempunyai kandungan selulosa $49 \%$, lignin $26,8 \%$, pentosa $15,6 \%$, abu $0,6 \%$ dan silika 0,2\% (Martawiyaja, 2005 dan Hapsari, 2014). Menurut Suryaningsih (2006), penggunaan media serbuk kayu sengon dan bekatul dapat menaikan bobot segar jamur tiram putih. Serbuk kayu merupakan bahan dasar pembuatan media tanam (baglog) yang mengandung karbohidrat, serat organik (selulosa, hemiselulosa) dan lignin yang dibutuhkan jamur untuk tumbuh dan berkembang.

Komposisi media untuk budidaya jamur tiram menurut Chazali dan Putri (2012) adalah serbuk kayu $100 \mathrm{~kg}$, dedak halus 10 $\mathrm{kg}$ dan kapur $0,5 \mathrm{~kg}$. Namun, ketersediaan serbuk kayu mulai langka disebabkan berkurangnya potensi hutan dan penggunaan serbuk kayu untuk industry lain. Oleh karena itu perlu dicari alternatif sebagai substitusi media tanam jamur tiram putih, misalnya dengan sekam padi.

Sekam padi merupakan bagian dari bulir padi, dihasilkan $20 \%$ dari berat gabah setiap penggilingan, mengandung serat tinggi dengan komposisi utama selulosa 33\% sampai $44 \%$, lignin $19 \%$ sampai $47 \%$, hemiselulosa $17 \%$ sampai $26 \%$, pentosa $16,94 \%$ sampai $21,95 \%$ dan silika $13 \%$ (Sipuhantar, 2010). Berdasarkan komposisinya, sekam tersebut dapat digunakan sebagai campuran media tumbuh jamur tiram putih, karena jamur tiram putih memerlukan serat dalam proses tumbuh kembangnya. Menurut Suparti dan Marfuah (2015) penambahan sekam $15 \%$ kedalam media baglog mampu meningkatkan jumlah tubuh buah dan bobot segar jamur tiram putih.

Pada media tanam juga ditambahkan bekatul, merupakan hasil sisa penggilingan padi yang kaya vitamin terutama vitamin $B$ komplek, merupakan bagian yang berperan dalam pertumbuhan dan perkembangan miselium jamur serta berfungsi sebagai pemicu untuk pertumbuhan tubuh buah jamur (Suriawiria, 2002). Selain itu, ditambahkan kapur sebagai sumber kalsium (Ca) dan untuk mengatur pH media. Kapur yang digunakan adalah kapur pertanian yaitu karbonat $(\mathrm{CaCO} 3)$. Unsur kalsium dan karbon digunakan untuk meningkatkan mineral yang dibutuhkan jamur (Rachmatullah, 2010).

Jamur tiram putih bersifat heterotrop yaitu jamur tidak dapat memproduksi makanannya sendiri, sehingga jamur harus memperoleh energi dari bahan-bahan organik lainnya melalui hifa dan miselium, kemudian menyimpannya dalam bentuk glikogen. Miselium secara keseluruhan mempunyai kekuatan untuk mengabsorbsi nutrient. Miselium berhubungan langsung dengan substrat dan mengeluarkan enzim yang dapat memecah komponen organik kompleks menjadi komponen sederhana yang akhirnya dapat diserap secara difusi melalui dinding miselium (Sari dalam Mufarrihah, 2009). Jamur tiram putih 
memperoleh nutrisi dari serbuk kayu dan bahan lain diantaranya sekam padi (Chazali dan Pratiwi,2012).

Pada penelitian Suparti dan Marfuah (2015), penambahan sekam 15\% mampu meningkatkan jumlah tubuh buah dan bobot segar jamur tiram putih. Semakin banyak sekam yang ditambahkan kedalam media maka lignoselulosa sebagai sumber nutrisi jamur tiram akan semakin banyak, namun hal tersebut membuat kandungan silika pada media juga semakin banyak sehingga akan menghambat proses degradasi lignoselulosa (Hartati, 2011). Muchsin dkk. (2017) menyatakan bahwa penambahan sekam $15 \%$ dan bekatul $15 \%$ dapat menghasilkan jumlah tubuh buah jamur tertinggi. Hapsari (2014) menyatakan bahwa penambahan sekam padi dengan serbuk kayu jati 15\% berpengaruh terhadap bobot segar badan buah dan jumlah tubuh buah jamur tiram, akan tetapi tidak berpengaruh terhadap lama penyebaran miselium.

Atas dasar penjelasan bahwa sekam padi dapat digunakan sebagai campuran pada media tanam jamur tiram putih sebagai substitusi serbuk kayu, namun perbedaan komposisi akan menyebabkan pertumbuhan dan hasil yang berbeda karena kandungan nutrisi yang berbeda. Penelitian dilakukan dengan maksud untuk menguji komposisi media antara serbuk kayu dan sekam padi pada budidaya jamur tiram putih, adapun tujuan dari penelitian ini adalah untuk mengetahui komposisi media anatara serbuk kayu dan sekan padi yang baik untuk pertumbuhan dan hasil jamur tiram putih.

\section{METODE PENELITIAN}

Penelitian dilaksanakan di Desa Cihikeu, Kecamatan Bungbulang, Kabupaten Garut dengan ketinggian tempat $500 \mathrm{~m}$ di atas permukaan laut, pada bulan Maret sampai dengan Juni 2019. Alat yang digunakan adalah kumbung, rak bertingkat dari bambu, gunting, tali rapia, kantong plastik $(17 \mathrm{~cm} \times 30 \mathrm{~cm})$, karet gelang, koran, cincin dari paralon, steamer, alat press manual, spatula, terpal, handsprayer, alat tulis, alat ukur, label. Bahan yang digunakan adalah serbuk kayu, sekam padi, bibit jamur tiram putih $\mathrm{F}_{1}$, air, kapur bekatul, M-Bio, dan alkohol 70\%.

Percobaan menggunakan Rancangan Acak Kelompok (RAK) dengan 5 perlakuan kompo- sisi media tanam dan ulangan 5 kali. Perlakuan komposisi media tanam adalah sebagai berikut: $p_{0}(100 \%$ serbuk kayu), $\mathrm{p}_{1}(15 \%$ Sekam padi $+85 \%$ serbuk kayu), $\mathrm{p}_{2}(30 \%$ Sekam padi $+70 \%$ serbuk kayu $), \mathrm{p}_{3}(45 \%$ Sekam padi $+55 \%$ serbuk kayu), $\mathrm{p}_{4}(60 \%$ Sekam padi $+40 \%$ serbuk kayu). Setiap perlakuan terdiri dari 6 baglog jamur tiram putih. Pemanenan jamur tiram dilakukan pada umur 40 hari setelah inokulasi dengan kriteria panen tudung jamur sudah mekar, dengan cara mencabut seluruh rumpun jamur.

Parameter yang diamati meliputi jumlah tubuh buah jamur per baglog, diameter tudung tubuh, diameter batang tubuh, tinggi batang tubuh, dan bobot basah tubuh. Untuk mengetahui pengaruh perlakuan, data diuji dengan Uji Fisher, selanjutnya menggunakan Uji Jarak Berganda Duncan (Gomez and Gomez, 1995).

\section{HASIL DAN PEMBAHASAN}

\section{Keadaan umum lokasi penelitian}

Temperatur harian selama percobaan pada bulan Maret sampai bulan Juni 2019, menunjukkan rata-rata temperatur $23^{\circ} \mathrm{C}$, jadi sesuai dengan syarat tumbuh jamur tiram putih yang menghendaki temperatur lingkungan antara $23^{\circ} \mathrm{C}$ sampai $28^{\circ} \mathrm{C}$ (Chazali dan Pratiwi, 2012). Kelembaban udara pada bulan Maret sampai bulan Juni 
2019 rata-rata $80 \%$, sesuai dengan syarat tumbuh jamur tiram putih yang menghendaki kelembaban lingkungan antara $75 \%$ sampai $80 \%$ (Chazali dan Pratiwi, 2012). Derajat kemasaman media yaitu 7 , sesuai dengan syarat pertumbuhan miselium jamur yang menghendaki $\mathrm{pH}$ netral yaitu 6 sampai 7 (Nurhakim, 2018).

Selama percobaan berlangsung, keadaan pertumbuhan jamur tiram putih secara umum baik, dan waktu yang dibutuhkan miselium untuk memenuhi baglog tercepat terdapat pada perlakuan tanpa penambahan sekam padi atau $100 \%$ serbuk kayu yaitu 20 hari setelah inokulasi. Selanjutnya pada komposisi media $15 \%$ sekam padi $+85 \%$ serbuk kayu dan $30 \%$ sekam padi $+70 \%$ serbuk kayu yaitu 22 hari setelah inokulasi, diikuti oleh perlakuan komposisi media $45 \%$ sekam padi $+55 \%$ serbuk kayu yaitu pada 25 hari setelah inokulasi. Terakhir pada komposisi media $60 \%$ sekam padi $+40 \%$ serbuk kayu yaitu dengan waktu 26 hari setelah inokulasi. Nampaknya semakin banyak sekam padi pada media tanam mengakibatkan semakin lama waktu untuk munculnya tubuh buah pertama. Hal itu disebabkan penambahan sekam padi yang terlalu banyak dapat meningkatkan kandungan silika di dalam media, sehingga pertumbuhan terhambat, karena miselium dan enzim sukar menembus dan mendegradasi silika (Zaman dan Sutrisno, 2006).

\section{Jumlah tubuh buah jamur}

Hasil analisis statistik menunjukkan komposisi media berpengaruh terhadap jumlah tubuh buah per baglog jamur tiram putih (5 kali panen) (Tabel 1)

Pada Tabel 1 nampak bahwa jumlah tubuh buah jamur per baglog pada perlakuan komposisi media $100 \%$ serbuk kayu dengan nilai rata-rata 36,76 berbeda nyata dengan perlakuan komposisi media $15 \%$ sekam padi $+85 \%$ serbuk kayu dengan nilai rata-rata 38,70 , perlakuan komposisi media $30 \%$ sekam padi $+70 \%$ serbuk kayu dengan nilai rata-rata 33,63, perlakuan komposisi media sekam padi $45 \%+$ serbuk $55 \%$ dengan nilai rata-rata 33,50 dan komposisi media 60\% sekam padi $+40 \%$ serbuk kayu dengan nilai rata-rata 24,27 .

Pada perlakuan komposisi media $15 \%$ sekam padi $+85 \%$ serbuk kayu jumlah tubuh buah jamur per baglog terbanyak dibandingkan dengan perlakuan lainnya. Menurut Sipuhantar (2010), sekam merupakan limbah yang mengandung serat dengan komposisi utama 33\% sampai 44\% selulosa, 19\% sampai $47 \%$ lignin, $17 \%$ sampai $26 \%$ hemiselulosa. Ketiga serat tersebut merupakan komponen utama pada media tumbuh jamur tiram, sehingga jamur tumbuh subur (Reyeki, 2013). Sedangkan pada perlakuan komposisi media $60 \%$ sekam padi $+40 \%$ serbuk kayu menunjukkan jumlah tubuh buah jamur paling sedikit. Hal ini disebabkan sekam dalam media terlalu banyak membuat kandungan silika pada media juga semakin banyak sehingga akan menghambat proses degradasi lignoselulosa (Hartati,2011).

Menurut Sipuhantar (2010), sekam mengandung silika $13 \%$. Sedangkan serbuk kayu mengandung silika 0,2\% (Martawijaya, 2015 dalam Hapsari, 2014). 
Tabel 1. Pengaruh komposisi media tanam terhadap jumlah tubuh buah jamur tiram putih.

$$
\text { Perlakuan Jumlah tubuh buah jamur per baglog }
$$

(buah)

\begin{tabular}{ll}
\hline $\mathrm{p}_{0}(100 \%$ serbukkayu $)$ & $36,76 \mathrm{c}$ \\
$\mathrm{p}_{1}(15 \%$ sekam padi $+85 \%$ serbukkayu $)$ & $38,70 \mathrm{~d}$ \\
$\mathrm{p}_{2}(30 \%$ sekam padi $+70 \%$ serbuk kayu $)$ & $33,63 \mathrm{~b}$ \\
$\mathrm{p}_{3}(45 \%$ sekam padi $+55 \%$ serbuk kayu $)$ & $33,50 \mathrm{ab}$ \\
$\mathrm{p}_{4}(60 \%$ sekam padi $+40 \%$ serbuk kayu $)$ & $24,27 \mathrm{a}$
\end{tabular}

Keterangan: Angka rata-rata yang ditandai huruf yang sama, tidak berbeda nyata menurut Uji JarakBerganda Duncan taraf nyata 5\%

\section{Diameter tudung tubuh buah jamur}

Hasil analisis statistik menunjukkan bahwa komposisi media berpengaruh terhadap diameter tudung tubuh buah jamur pada panen ke-1, 2, 3, 4 dan 5. Pada Tabel 2 terlihat bahwa pada panen ke 1 , perlakuan komposisi media $100 \%$ serbuk kayu menunjukan nilai rata- rata diameter tudung tubuh buah jamur $10,71 \mathrm{~cm}$, berbeda dengan perlakuan komposisi media $15 \%$ sekam padi $+85 \%$ serbuk kayu dengan nilai rata-rata diameter tudung tubuh buah jamur $9,77 \mathrm{~cm}$, perlakuan komposisi media 30\% sekam padi $+70 \%$ serbuk kayu dengan nilai rata-rata $9,53 \mathrm{~cm}$, perlakuan komposisi media $45 \%$ sekam padi $+55 \%$ serbuk kayu dengan nilai rata-rata $9,52 \mathrm{~cm}$ dan perlakuan komposisi media $60 \%$ sekam padi $+40 \%$ serbuk kayu dengan nilai $9,37 \mathrm{~cm}$.

Pada panen ke 2, perlakuan komposisi media $100 \%$ serbuk kayu menunjukkan nilai rata-rata diameter tudung tubuh buah jamur yaitu $10,23 \mathrm{~cm}$, tidak berbeda nyata dengan komposisi media $15 \%$ sekam padi $+85 \%$ serbuk kayu dengan nilai rata-rata $10,13 \mathrm{~cm}$, komposisi media $30 \%$ sekam padi $+70 \%$ serbuk kayu dengan nilai ratarata $10,01 \mathrm{~cm}$, tetapi berbeda nyata dengan komposisi media $45 \%$ sekam padi $+55 \%$ serbuk kayu dengan nilai rata-rata $6,96 \mathrm{~cm}$ dan komposisi media $60 \%$ sekam padi + $40 \%$ serbuk kayu dengan nilai $9,34 \mathrm{~cm}$.

Pada panen ke 3, perlakuan komposisi media $100 \%$ serbuk kayu menunjukkan nilai rata-rata diameter tudung tubuh buah jamur yaitu $10,06 \mathrm{~cm}$, berbeda nyata dengan komposisi media $15 \%$ sekam padi+ $85 \%$ serbuk kayu dengan nilai ratarata 9,68 cm, komposisi media $30 \%$ sekam padi $+70 \%$ serbuk kayu dengan nilai ratarata $9,41 \mathrm{~cm}$, komposisi media $45 \%$ sekam padi $+55 \%$ serbuk kayu dengan nilai ratarata $8,96 \mathrm{~cm}$ dan komposisi media $60 \%$ sekam padi $+40 \%$ serbuk kayu dengan nilai $8,57 \mathrm{~cm}$.

Pada panen ke 4, perlakuan komposisi media 100\% serbuk kayu menunjukkan nilai rata-rata diameter tudung tubuh buah jamur yaitu $9,80 \mathrm{~cm}$, berbeda nyata dengan komposisi media $15 \%$ sekam padi $+85 \%$ serbuk kayu dengan nilai rata-rata $9,04 \mathrm{~cm}$, komposisi media 30\% sekam padi $+70 \%$ serbuk kayu dengan nilai ratarata $8,78 \mathrm{~cm}$, komposisi media $45 \%$ sekam padi $+55 \%$ serbuk kayu dengan nilai ratarata $8,66 \mathrm{~cm}$ dan komposisi media $60 \%$ sekam padi $+40 \%$ serbuk kayu dengan nilai rata-rata $8,66 \mathrm{~cm}$.

Pada panen ke 5, perlakuan komposisi media 100\% serbuk kayu menunjukkan nilai rata-rata diameter tudung tubuh buah jamur yaitu $9,76 \mathrm{~cm}$, berbeda nyata dengan komposisi media 15\% sekam padi $+85 \%$ serbuk kayu dengan nilai rata-rata $8,58 \mathrm{~cm}$, komposisi media 30\% sekam padi $+70 \%$ serbuk kayu dengan nilai ratarata $7,97 \mathrm{~cm}$, komposisi media $45 \%$ sekam 
Tabel 2. Pengaruh komposisi media terhadap diameter tudung buah jamur tiram putih panen ke $1,2,3,4$ dan 5 .

\begin{tabular}{lccccc}
\hline \multirow{2}{*}{ Perlakuan } & \multicolumn{4}{c}{ Diameter tudung tubuh buah } \\
\cline { 2 - 5 } & Panen 1 & Panen 2 & Panen 3 & Panen4 & Panen 5 \\
\hline $\mathrm{p}_{0}(100 \%$ serbukkayu $)$ & $10,71 \mathrm{c}$ & $10,23 \mathrm{c}$ & $10,06 \mathrm{~d}$ & $9,80 \mathrm{~d}$ & $9,76 \mathrm{~d}$ \\
$\mathrm{p}_{1}(15 \%$ sekam padi + $85 \%$ serbukkayu $)$ & $9,77 \mathrm{~b}$ & $10,13 \mathrm{c}$ & $9,68 \mathrm{c}$ & $9,04 \mathrm{c}$ & $8,58 \mathrm{c}$ \\
$\mathrm{p}_{2}(30 \%$ sekam padi + $70 \%$ serbuk kayu $)$ & $9,53 \mathrm{ab}$ & $10,01 \mathrm{bc}$ & $9,41 \mathrm{c}$ & $8,78 \mathrm{~b}$ & $7,97 \mathrm{bc}$ \\
$\mathrm{p}_{3}(45 \%$ sekam padi + $55 \%$ serbuk kayu $)$ & $9,52 \mathrm{ab}$ & $6,96 \mathrm{ab}$ & $8,96 \mathrm{~b}$ & $8,66 \mathrm{a}$ & $7,69 \mathrm{ab}$ \\
$\mathrm{p}_{4}(60 \%$ sekam padi + $40 \%$ serbuk kayu $)$ & $9,37 \mathrm{a}$ & $9,34 \mathrm{a}$ & $8,57 \mathrm{a}$ & $8,66 \mathrm{a}$ & $7,17 \mathrm{a}$ \\
\hline
\end{tabular}

Keterangan: Angka rata-rata yang ditandai huruf yang sama pada tiap kolom berbeda tidak nyata menurut Uji Jarak Berganda Duncan taraf nyata 5\%

padi $+55 \%$ serbuk kayu dengan nilai ratarata $7,69 \mathrm{~cm}$ dan komposisi media $60 \%$ sekam padi $+40 \%$ serbuk kayu dengan nilai rata-rata $7,17 \mathrm{~cm}$.

Ukuran diameter tudung buah dipengaruhi oleh jumlah tubuh buah jamur yang tumbuh. Semakin banyak jumlah tubuh buah yang tumbuh, maka semakin kecil diameternya (Aini dan Kuswytasari, 2013). Hal ini disebabkan nutrisi yang terdapat dalam media akan tersebar pada setiap tubuh buah yang tumbuh jika seluruh calon badan buah dapat berhasil tumbuh menjadi tubuh buah jamur tiram, maka nutrisi dalam media akan ditranslokasikan untuk mendukung partum- buhan setiap badan buah. Tetapi jika calon tubuh buah jamur sedikit jumlahnya, maka suplai nutrisi dari media akan terakumulasi pada pembentukan diameter tudung buah (Muchsin, 2017).

\section{Diameter batang tubuh buahjamur}

Hasil analisis statistik menunjukkan bahwa komposisi media berpengaruh nyata terhadap diameter batang pada panen ke-5 tetapi tidak berbeda pada panen ke 1, 2, 3 dan 4 (Tabel 3).

Pada Tabel 3 terlihat bahwa pada panen ke 1 , panen ke 2, panen ke 3 dan panen ke 4 menunjukkan antar perlakuan berbeda tidak nyata terhadap diameter batang tubuh buah jamur tiram putih. Tetapi pada panen ke 5 antara perlakuan terdapat perbedaan nyata. Perlakuan komposisi media $15 \%$ sekam padi $+85 \%$ serbuk kayu menunjukan rata-rata diameter batang tubuh buah jamur paling besar yaitu $1,12 \mathrm{~cm}$ tetapi tidak berbeda nyata dengan komposisi media $100 \%$ serbuk kayu dengan nilai rata-rata 1,06 , tetapi berbeda nyata dengan komposisi media sekam lainnya. Komposisi media $60 \%$ sekam padi $+40 \%$ serbuk kayu menunjukkan nilai terkecil, berbeda tidak nyata dengan media $30 \%$ sekam padi + $70 \%$ serbuk kayu, komposisi media $45 \%$ sekam padi $+55 \%$ serbuk kayu

Diameter batang tubuh buah jamur pada panen pertama sampai panen ke empat berbeda tidak nyata, tapi berbeda nyata pada panen ke lima. Hal ini disebabkan ukuran diameter batang buah jamur dipengaruhi oleh jumlah tubuh buah jamur yang tumbuh. Semakin banyak jumlah tubuh buah yang tumbuh, maka semakin kecil diameternya (Aini dan Kuswytasari,2013). 
Tabel 3. Pengaruh komposisi media terhadap diameter batang tubuh buah jamur tiram putih panen ke 1, 2, 3, 4 dan 5 .

\begin{tabular}{lccccc}
\hline \multirow{2}{*}{ Perlakuan } & \multicolumn{5}{c}{ Diameter batang tubuh buah } \\
\cline { 2 - 6 } & Panen1 & Panen2 & Panen3 & Panen4 & Panen 5 \\
\hline $\mathrm{p}_{0}(100 \%$ serbukkayu $)$ & $1,40 \mathrm{a}$ & $1,28 \mathrm{a}$ & $1,06 \mathrm{a}$ & $1,14 \mathrm{a}$ & $1,06 \mathrm{bc}$ \\
$\mathrm{p}_{1}(15 \%$ sekam padi + 85\% serbukkayu) & $1,38 \mathrm{a}$ & $1,14 \mathrm{a}$ & $1,32 \mathrm{a}$ & $1,06 \mathrm{a}$ & $1,12 \mathrm{c}$ \\
$\mathrm{p}_{2}(30 \%$ sekam padi + 70\% serbuk kayu $)$ & $1,42 \mathrm{a}$ & $1,18 \mathrm{a}$ & $1,12 \mathrm{a}$ & $1,08 \mathrm{a}$ & $1,00 \mathrm{ab}$ \\
$\mathrm{p}_{3}(45 \%$ sekam padi + 55\% serbuk kayu $)$ & $1,34 \mathrm{a}$ & $1,26 \mathrm{a}$ & $1,08 \mathrm{a}$ & $1,02 \mathrm{a}$ & $1,00 \mathrm{ab}$ \\
$\mathrm{p}_{4}(60 \%$ sekam padi + 40\% serbuk kayu $)$ & $1,26 \mathrm{a}$ & $1,12 \mathrm{a}$ & $1,02 \mathrm{a}$ & $1,02 \mathrm{a}$ & $0,94 \mathrm{a}$ \\
\hline
\end{tabular}

Keterangan: Angka rata-rata yang ditandai huruf yang sama pada tiap kolom berbeda tidak nyata menurut Uji Jarak Berganda Duncan taraf nyata 5\%

\section{Tinggi batang tubuh buahjamur}

Hasil analisis statistik menunjukkan perlakuan komposisi media berpengaruh nyata terhadap tinggi batang tubuh buah jamur pada panen ke-1 sampai ke-5 (Tabel 4).

Pada Tabel 4 terlihat bahwa pada panen ke 1 dan ke 2, perlakuan komposisi media $100 \%$ serbuk kayu menunjukkan nilai rata- rata tinggi batang tubuh buah jamur tertinggi, berbeda nyata dengan komposisi media lainnya. Komposisi media 60\% sekam padi $+40 \%$ serbuk kayu menunjukkan nilai terkecil tetapi berbeda tidak nyata dengan komposisi media $45 \%$ sekam padi $+55 \%$ serbuk kayu (Tabel 4 ).

Tabel 4. Pengaruh komposisi media terhadap tinggi batang tubuh buah jamur tiram putih pada panen ke 1,2, 3, 4 dan5.

\begin{tabular}{lccccc}
\hline Perlakuan & \multicolumn{5}{c}{ Tinggi batang tubuh buahjamur(cm) } \\
\cline { 2 - 6 } & Panen 1 & Panen 2 & Panen 3 & Panen 4 & Panen 5 \\
\hline $\mathrm{p}_{0}(100 \%$ serbukkayu) & $9,93 \mathrm{c}$ & $9,83 \mathrm{c}$ & $8,84 \mathrm{~b}$ & $9,51 \mathrm{~d}$ & $7,01 \mathrm{c}$ \\
$\mathrm{p}_{1}(15 \%$ sekam padi + 85 \% serbukkayu) & $8,24 \mathrm{~b}$ & $8,50 \mathrm{~b}$ & $7,68 \mathrm{a}$ & $7,82 \mathrm{c}$ & $6,86 \mathrm{bc}$ \\
$\mathrm{p}_{2}(30 \%$ sekam padi + 70 \% serbuk kayu) & $8,00 \mathrm{~b}$ & $8,48 \mathrm{~b}$ & $7,74 \mathrm{a}$ & $6,84 \mathrm{~b}$ & $6,64 \mathrm{bc}$ \\
$\mathrm{p}_{3}(45 \%$ sekam padi + 55\% serbuk kayu $)$ & $7,25 \mathrm{a}$ & $7,64 \mathrm{a}$ & $7,13 \mathrm{a}$ & $5,93 \mathrm{ab}$ & $6,41 \mathrm{ab}$ \\
$\mathrm{p}_{4}(60 \%$ sekam padi + 40\% serbuk kayu $)$ & $6,93 \mathrm{a}$ & $7,57 \mathrm{a}$ & $7,29 \mathrm{a}$ & $6,96 \mathrm{~b}$ & $6,28 \mathrm{a}$ \\
\hline
\end{tabular}

Keterangan: Angka rata-rata yang ditandai huruf yang sama pada tiap kolom, tidak berbeda nyata menurut Uji Jarak Berganda Duncan taraf nyata 5\%

Pada panen ke 3, perlakuan komposisi media $100 \%$ serbuk kayu menghasilkan tinggi batang tubuh buah jamur tertinggi yaitu $8,84 \mathrm{~cm}$, dan berbeda nyata dengan perlakuan komposisi media lainnya. Pada panen ke 4, komposisi media 100\% serbuk kayu menghasilkan nilai rata-rata tinggi batang tubuh buah jamur tertinggi yaitu $9,51 \mathrm{~cm}$, berbeda nyata dengan komposisi media lainnya. Pada panen ke 5, perlakuan komposisi media $100 \%$ serbuk kayu menunjukkan nilai rata-rata tinggi batang tubuh buah jamur tertinggi yaitu $7,01 \mathrm{~cm}$, tetapi berbeda tidak nyata dengan komposisi media $15 \%$ sekam padi $+85 \%$ serbuk kayu dan komposisi media 30\% sekam padi $+70 \%$ serbuk kayu, tetapi berbeda nyata dengan komposisi media $45 \%$ sekam padi $+55 \%$ serbuk kayu dan komposisi media $60 \%$ sekam padi $+40 \%$ serbuk kayu. Tinggi batang tubuh buah pada setiap media tanpa campuran sekam padi, hasilnya lebih baik dari komposisi media yang dicampurkan. Hal ini sesuai dengan pernyataan Ipuk dan Saparinto (2010) dalam Lukman (2012) yang 
menyatakan bahwa jamur akan tumbuh subur pada bahan-bahan yang terdekomposisi, sehingga formulasi media dan penambahan unsur-unsur lain yang dibutuhkan oleh jamur secara tepat bisa meningkatkan produktivitas, pertimbangan efisiensi dan efektivitas produksi.

Tabel 5. Pengaruh komposisi media terhadap total bobot basah tubuh buah jamur tiram putih.

\begin{tabular}{cc}
\hline Perlakuan & bobot basah tubuh buah jamur $(\mathrm{g})$ \\
\hline $\mathrm{p}_{0}(100 \%$ serbukkayu $)$ & $471,82 \mathrm{bc}$ \\
$\mathrm{p}_{1}(15 \%$ sekam padi $+85 \%$ serbukkayu $)$ & $493,98 \mathrm{c}$ \\
$\mathrm{p}_{2}(30 \%$ sekam padi $+70 \%$ serbuk kayu $)$ & $456,42 \mathrm{~b}$ \\
$\mathrm{p}_{3}(45 \%$ sekam padi $+55 \%$ serbuk kayu $)$ & $416,28 \mathrm{a}$ \\
$\mathrm{p}_{4}(60 \%$ sekam padi $+40 \%$ serbuk kayu $)$ & $408,38 \mathrm{a}$ \\
\hline
\end{tabular}

Keterangan: Angka rata-rata yang ditandai huruf yang sama pada tiap kolom berbeda tidak nyata menurut Uji Jarak Berganda Duncan taraf nyata 5\%

\section{Bobot basah tubuh buah jamur per baglog}

Hasil analisis statistik menunjukan komposisi media berpengaruh terhadap bobot basah tubuh buah jamur tiram putih per baglog (Tabel 5).

Pada Tabel 5 terlihat bahwa pada perlakuan komposisi media15\% sekam padi $+85 \%$ serbuk kayu menunjukkan nilai rata-rata total bobot basah tubuh buah tertinggi yaitu 493,98 , tetapi tidak berbeda dengan komposisi media sekam padi 100\% serbuk kayu. Penambahan sekam padi yang tidak terlalu banyak menyebabkan proses degradasi lignoselulosa berjalan dengan baik (Hartati, 2011). Bobot basah tubuh buah jamur tiram putih berhubungan dengan banyaknya jumlah tubuh buah, ditunjukkan pada Tabel 1. Menurut Hartati (2011) bobot jamur tiram dipengaruhi oleh jumlah tubuh buah yang berhasil tumbuh.

\section{KESIMPULAN DAN SARAN}

\section{Kesimpulan}

Pertumbuhan dan hasil jamur tiram putih berbeda pada setiap komposisi media yang dicoba. Pertumbuhan dan hasil terbaik dihasilkan oleh perlakuan komposisi media $15 \%$ sekam padi $+85 \%$ serbuk kayu, menghasilkan jumlah tubuh buah jamur sebanyak 38,70 buah dan bobot basah tubuh buah jamur 493,98 g per baglog.

\section{Saran}

1. Untuk menghasilkan pertumbuhan dan hasil jamur tiram putih yang baik dapat digunakan media dengan komposisi $15 \%$ sekam padi $+85 \%$ serbuk kayu.

2. Perlu dilakukan penelitian lebih lanjut dengan waktu pengomposan yang lebih lama dan pemberian decomposer yang lebih banyak. 


\section{DAFTAR PUSTAKA}

Aini, F.N. dan Kuswytasari, N.D. 2013. Pengaruh Penambahan Eceng Gondok (Eichornia crassipes) terhadap Pertumbuhan Jamur Tiram Putih (Pleurotus ostreatus). Jurnal Sains dan Seni POMITS. 2(1).

Angelia dan Nurmiati. 2013. Pengaruh Lama Pelapukan Media Limbah Industri The terhadap Pertumbuhan Miselium Produksi Jamur Kuping Hitam (Auricularia polytrica Sacc). Jurusan Biologi Universitas Andalas. J. Bio. UA. 2(4): 269-276.

Chazali, Syammahfuz dan Putri Sekar Pratiwi. 2012. Usaha Jamur Tiram Skala Rumah Tangga. Penebar Swadaya, Jakarta.

Djarijah N.M. dan Djarijah A.S. 2001. Budidaya Jamur Tiram. Kanisius, Yogyakarta.

Gomez, Kwanchai A. dan Arturo A. Gomez. 1995. Prosedur Statistik untuk Penelitian Pertanian. Universitas Indonesia. Jakarta.

Hapsari, W.E. 2014. Pertumbuhan dan Produktivitas Jamur Tiram Putih (Pleurotus ostreatus) pada Media Serbuk Kayu Jati (Tectona Grandis L.) dengan Penambahan Sekam Padi (Oryza sativa). Naskah Publikasi. Universitas Muhamadiyah Surakart

Hartati, E.W. Tini dan A.R. Ayu. 2011. Kajian Pertumbuhan dan Hasil Cendawan Tiram Putih (Pleurotus ostreatus) pada Berbagai Komposisi Medium Tanam. Jurnal Pembangunan Pedesaan. 11(1): 37-44.

Lukman, Angga Muhammad. 2010. Pengaruh Komposisi Media Tanam Ampas Aren dan Serbuk Kayu dengan Lama Waktu Pengomposan terhadap Hasil Jamur Tiram Putih (Pleurotus ostreatus).Skripsi: Universitas Siliwangi.

Martawijaya, Kartasujana, A.I., Mandang, Y.I., Prawira, S.A, dan Kadir, k. 2005. Atlas KayuIndonesia Jilid II. Badan
Penelitian dan Pengembangan

Kehutanan Departemen Kehutanan, Bogor.

Muchsin, Ali Yazid., Wisnu Eko Murdiono dan Moch. Dawam Maghfoer. 2017. PengaruhPenambahan Sekam Padi dan Bekatul Terhadap Pertumbuhan dan Hasil Jamur Tiram Putih (Pleurotus ostreatus). PLANTROPICA Journal of Agriculture al Science. 30-38.

Mufarrihah. 2009. Pengaruh Penambahan Bekatul dan Ampas Tahu pada Media terhadap Pertumbuhan dan Produksi Jamur Tiram Putih (Pleurotus ostreatus).

Nurhakim, Y.I., 2018. Sukses Budidaya Jamur Tiram. Bumi Pamulang. ISBN: 978-602-6724-14-4. 7-9. Periadnadi, Mitra

Rachmatullah. 2010. Bahan-bahan Baku Media Jamur Tiram. [Online]. Tersedia :https://bisnisjamur.wordpress.com/tag /serbuk-kayu(21 Januari 2019).

Reyeki, Setyowati. 2013. Pemanfaatan Serbuk Gergaji Kayu Sengon (Albizia falcataria) dan Bekatul sebagai Media Tanam Budidaya Jamur Tiram Putih (Pleurotus ostreatus) dengan penambahan Serbuk Sabut Kelapa (Cocos nucifera). Skripsi. Universitas Muhammadiyah Surakarta.

Sipuhantar, D. 2010. Teknologi Briket Sekam Padi. Balai Pengkajian Teknologi Pertanian (BPTP), Riau.

Suparti dan Lismiyati Marfuah. 2015. Produktivitas Jamur Tiram Putih (Pleurotus ostreatus) pada Media Limbah Sekam Padi dan Daun Pisang Kering sebagai Media Alternatif. Bioeksperimen. Volume 1 No.2.

Suriawira, U. 2002. Budidaya Jamur Tiram. Yayasan. Kanisius, Jogjakarta.

Suryaningsih, E., Sumiati, E., Puspitasari. 2006. Journal Hortikultura. Indonesia.

Soenanto, Hardi. 2000. Jamur Tiram, Budidaya dan Peluang Usaha. Semarang: Aneka Ilmu 
Sunanto, H. 2002. Budidaya Jamur Tiram.

CV. Aneka Ilmu, Semarang.

Suriawiria, U. 2010. Budidaya Jamur

Tiram. Kanisius. Yogyakarta.

Wilandari. 2014. Produktivitas Jamur

Tiram (Pleurotus ostreatus) pada

Media Campuran Serbuk Gergaji

Serasah Daun Pisang dan Bekatul.

Zaman, B. dan E. Sutrisno. 2006.

Kemampuan Penyerapan Eceng

Gondok Terhadap Amoniak dalam

Limbah Rumah Sakit Berdasarkan

Umur dan Lama Kontak (Studi

Kasus: RS Panti Wilasa Semarang).

Jurnal Presipitasi 1(1). 